\title{
Utilisation of payment instruments at a retail chain in Gauteng
}

\begin{abstract}
Authors:
Adriaan M. Bester ${ }^{1}$

Seugnet Bronkhorst ${ }^{1}$

Affiliations:

${ }^{1}$ Faculty of Management, University of Johannesburg, South Africa

Correspondence to: Seugnet Bronkhorst

Email:

sbronkhorst@uj.ac.za

Postal address:

PO Box 301, Rantendal 1751,

South Africa

Dates:

Received: 25 Mar. 2015

Accepted: 27 July 2015

Published: 30 Oct. 2015

How to cite this article: Bester, A.M. \& Bronkhorst, S., 2015, 'Utilisation of payment instruments at a retail chain in Gauteng', Acta Commercii 15(1), Art. \#318, 7 pages. http://dx.doi.org/10.4102/ ac.v15i1.318

\section{Copyright:}

C 2015. The Authors Licensee: AOSIS

OpenJournals. This work is licensed under the Creative Commons Attribution License.
\end{abstract}

Purpose: The purpose of this research was to determine the influence of race and income on the preferred payment instrument at pay points in a retail store in Pretoria Gauteng.

Problem investigated: The method of payment, as well as the way these payment methods have been utilised, has evolved throughout history. Cash has stayed at the top of the payment instrument deck as a payment choice for the past 10 decades. With the expansion of technology payment instruments evolved to facilitate exchange between merchant and consumer. The preferred method of payment at a retail store in Gauteng, indicating whether consumers prefer cash payments or the use of cards was investigated. Further to this the difference in payment method between the different races and income groups was identified.

Methodology: A quantitative survey research method was used. The statistical analysis entailed correlations using the Cramer's V to test the dependency between two variables and the degree of dependency of variables, after which the Chi-Square test was also applied.

Value of the research: The indication of consumer preference of payment method will have implications on which possibilities are available at the point of sale. Cash is no longer the only possible payment instrument; cards, debit and credit, are as easily used by consumers. Both banks and merchants will find this information important, since they need to make provision for different payment options. The results further distinguished consumer behaviour amongst different race groups and income groups.

Conclusion: The research confirmed the previous findings in other countries that consumers have preconceived ideas on which payment instrument they would utilise at point of sale (POS.)

\section{Introduction}

The use of different payment instruments has been around for centuries. Since the genesis of money 3000 BC (Todorova 2009), tremendous change has taken place in payment instruments, and currently the online debit card payment method has been accepted widely. Retail stores in South Africa have used the card system since early 2002 (Shoprite 2002). Several empirical studies have been conducted on payment systems in developed countries, and more specifically interest is shown in the utilisation of payment instruments across multiple continents, including America and Europe (Bounie, François \& Houy 2007; Mann 2011). Over the last few years payment system experts have predicted that a paperless, plastic payment system is imminent. In 1984 already Americans were able to withdraw funds from an automatic teller machine (ATM) by making use of their debit cards and have access to the funds immediately. This feat dubbed debit cards as the precursors of electronic money at the point of sale (Weinstein 1984).

Different payment instruments are essential as part of a payment system. Nowadays payment cards, credit transfers, direct debits and cheques are all known as non-cash payment instruments with which funds may be transferred between accounts.

However, what is happening in developing countries such as South Africa? Consumers have various options of payment instruments and may use cash, debit cards, credit cards, e-wallets, prepaid cards and mobile payment where available. All these payment instrument choices are either in the consumer's wallet or on their mobile phone (Contini 2012). In South Africa, $68 \%$ of consumers have credit cards, of which the older age group of $65+$ carries $83 \%$ of the credit cards in their wallets, whilst $85 \%$ of these consumers earn on average R300 000 per year (DataMonitor 2011). Further analysis by DataMonitor into the South African card market indicates that $33 \%$ of all consumers that hold prepaid cards in their wallets earn on average between R150 000 and R190 000 per year and spend most of their prepaid value on regular spending (DataMonitor 2011). 
Much research has been conducted on the effect of payment behaviour and attributes of the consumers making the payments, but these studies provide limited insights into who the consumers are that choose a specific payment instrument (Schuh \& Stavins 2010) A recent report released by Verifone indicated that $67 \%$ of the adult population in South Africa is unbanked, or does not use a bank (Verifone 2013). Gustav Vermaas, Standard Bank Head for Mobile and Internet Banking in South Africa, advised at a conference in Sandton that there are 13 million unbanked adults in South Africa that made R8 billion cash deposits in 2012 (Mittner 2013). Walter Volker, chairman of the Payments Association of South Africa (PASA), stated at the same conference that credit cards were utilised in one out of every two transactions in 2012, whilst there had been positive growth in the usage of debit cards in 2012, with an increase from $13 \%$ to $18 \%$ (Mittner 2013). As South Africa is seen as a developing economy, it is important to understand how South Africans in general use their payment instruments to pay for goods and services. From the increase in the usage of debit cards, it can be deduced that more people are moving into the banking population. The aim of this article was to report on the role of race and income in the choice of the payment instrument.

\section{Literature review}

Payment instruments and consumer payment behaviour have evolved throughout history, mainly because of changes in the technology sphere (Leinonen 2009). These technological advances have an impact on how consumers pay, and payment habits of the general public (Leinonen 2009). Cash is and has been the primary payment instrument utilised by consumers, specifically for retail purchases for the last 150 years (Humphrey 2004). Payment system experts have predicted that the use of cash as a payment instrument will reduce and debit cards issued by Visa and MasterCard will replace cash as the payment instrument of choice (Carow \& Staten 1999).

In answering the question of how consumers will pay for goods and services in the future or whether cash as a payment instrument will stand the test of time, it is important to understand that the consumer enjoys the anonymity, universal acceptability and recognisability of cash with which both the consumer and merchant receive immediate satisfaction through the exchange of goods and the settlement thereof (Gogoski 2012).

A driving force for a consumer when selecting between payment instruments is the costs associated with each instrument. These costs are usually fixed and varied. Costs that are driven by currency for small purchases has a low fixed but high variable cost, whilst high fixed, but low variable costs are more effective for big payments where electronic payments are more efficient (Ten Raa \& Shestalova 2004). Another driver for the selection of payment instrument types is the speed at which the transaction can be completed. Recent research conducted in Poland making use of video cameras applied time and motion studies on
4000 transactions taking place at POS and found that, in general, cash is still the fastest means of payment, but that Near Field Communication (NFC) and proximity cards are in some cases equally fast or even faster (Polasik et al. 2010). Empirical research indicated that a lower level of currency in circulation leads to an increase in the utilisation of debit and credit cards, which in turn lowers the demand for hard cash, which in turn decreases seignorage income for central banks (Ramlall 2010).

Credit card usage is popular because the consumer can receive the product or service immediately, pay later, earn rewards and are protected against fraud. Using a credit card also enables the consumer to build up a better credit rating than with a debit card, which is utilised more where consumers want to enforce a limit on their spending, not have any bills to pay on a buy-now-pay-later scenario and reduce opportunity cost due to the substitution of the credit by debit card (Cohn 2010). Where reward programs to entice the card holder to opt for purchasing with a card, surcharge over and above the purchase price of commodities has a negative impact on the utilisation of debit cards by consumers who are steering away from making payments with cards instead of cash (Bolt, Jonker \& Van Renselaar 2010).

Visa and MasterCard branded cards are accepted at most merchants that utilise POS devices to generate the payment transaction (Vickers 2005). POS devices are wide-spread amongst merchants and are not only utilised to generate EFT payments, but can also have additional benefits to the issuers and merchants; as well as for consumer segmentation and market penetration purposes (Bizhani \& Tarokh 2010). The main objective of the POS system is to obtain the card holder's card detail, requesting for an authorisation and providing the authorisation reply to the terminal administrator. Secondly, the POS device ensures a fast and secure method of electronic funds transfers (EFT) (Zdravkovic 1988).

Holmes (2011:11) commented on the drivers and enablers of change in the way consumers in Africa pay. He noted three aspects that were fundamental to the adjustment of human behaviour, and stated that people were sluggish to adopt new payment enablers. (Holmes 2011). Holmes' theories were based on two-sided demand-and-supply-of-payment systems that were fuelled by technology expansion. The expansion in technology generated economic benefit, but may lead to new and unanswered questions for policy makers. These questions may relate to the wholesale payment systems including access, liquidity and systemic risk to the banking environment. Retail payment policies, on the other hand, deals with issues related to healthy competition, fraud and cross-border coordination (Kahn \& Roberds 2009).

An investigation into the key factors affecting the adoption of information, communication and technology in South Africa showed that the requirement for the adoption of technology is influenced by the international environment 
and that policies and procedures set by governing bodies do not influence the adoption of technology at all (Kyobe 2011). At the centre of payments policy maker issues and decisions are the self-governing decisions of consumers, who opt to make a purchase with a specific payment instrument, which is impacted by merchants who can either accept or reject the form of payment from the consumer tendered for a transaction (Borzekowski \& Kiser 2008).

Consumer decision drivers in terms of payment forms will be influenced by factors such as demographics and attributes of the instruments (Borzekowski \& Kiser 2008). Much research has been conducted on the effect of payment behaviour and attributes of the consumers making the payments, but the data has provided limited insights into why consumers choose a specific payment instrument (Schuh \& Stavins 2010). In a competitive market payment type acceptance it is imperative for merchants to accept both cash and card payments with each of these payment types subject to consumer choice at merchant POS, and each with its own benefits and drawbacks (Arango \& Taylor 2009). Merchants will have to accept cash for years to come still, as total cash spending is forecast to increase, although slower than its historical growth, which, contrary to popular reports, suggests that payment by means of cash is not disappearing (Evans et al. 2013).

Several reasons for cash not being phased out soon are because of the inaccurate measurement of cash payments by consumers as well as an increase in cash usage, although the total amount of cash spent is declining. Other deciding variables include government and banks that are central to the longevity of cash; cash is highly correlated to the innovation of new payment methods and those adopting new innovative payment measures. (Evans et al. 2013).

South Africa's National Payment System is well-developed, and continuous innovative ideas are enabling the consumer to make payments in different ways. PayGate and First National Bank (FNB) created the new payment method for FNB clients to use mobile technology to make payments (Paygate 2008).

There are several reasons why it is necessary to understand how consumers utilise their payment instruments. The government need information when setting monetary policies. Banks and card associations need to provide payment facilities and thus take an interest in the utilisation of payment instruments by consumers. From a merchant perspective, it is important to understand what is important to a consumer and how consumers would prefer to pay for their goods or services. This allows merchants to become more consumer-focused and actively involved in enabling consumers to pay for goods and services.

Borzekowski and Kiser (2008:892) established that the money supply in circulation in a country at a specific time has an impact on card transactions. This implies that, if the monetary policy committee advises an increase in the interest rate, the money supply in the circulation will decline, as consumers are forced to reduce spending because of higher settlement amounts on credit. In difficult economic times it would force customers who are already cash-strapped to make use of credit cards as payment instruments. This is a never-ending downward spiral, as cash is then utilised to service some credit.

\section{Research methodology}

The paradigm relevant in the study is positivism. Positivism is used in quantitative research, but there are some elements shown in the thematic analysis that quantify a portion of the results (keeping in mind that these results are based on subjective information provided). The open-ended questions were analysed with quantitative context analysis.

The quantitative data was collected at a retail store in Gauteng, which required the purposively selected survey participants to answer questions regarding demographics as well as variables relating to process, budget, physical features of payment instrument, utility of the payment instrument and efficient combinations between the payment instruments.

The quantitative data was utilised in order to obtain a reliable population sample size for the various payment methods done within a specific time frame in the month. A ratio estimation technique was used to specify the appropriate sample size for the research to be conducted. The suggested sample size of the population was 100 surveys to be conducted with the consumers in the retail store. The research aimed to add to the quality and accessibility of new information on the utilisation of payment instruments at a large retail store. In this study a cross-sectional design was used to allow the researcher to establish predominance with measurement completed at one point in time. It took the form of structured questionnaires.

The questionnaires included five separate questions on biographical information, such as race, age, education level and income. The general questionnaire consisted of questions on the use of cash as the preferred method of payment and ten questions on the use of the card as payment, including both debit and credit cards. This made it possible to determine the relationship between the biographical information of the respondent and the method of payment used.

The statistical analysis techniques that were utilised in the quantitative analysis in this study in order to answer the research question truthfully were the Chi-Square test and Cramer's V. When analysing the spread of the variables, another tool that may be utilised is known as cross-tabulation that presents a joint frequency based on two variables. (Howell 2014). When there is a dependency between the two variables one can make use of the Cramers' V or Somer's D to understand and describe the degree of dependency between these variables and/or how they vary with other variables (Michael 2014). 
Assumptions that can be made on the Chi-Square test of Independence are that the lowest expected frequency in any cell should be 5 or more. Other authors have suggested less rigorous criteria and advised that, if at least $80 \%$ of the cells have an expected frequency of 5 or more, it is still acceptable (Pallant 2007). The first validation to perform is whether the data have disrupted one of the assumptions of Chi-Square concerning the minimum expected cell frequency which either should be greater than 5 or that $80 \%$ of cells have at least the frequency of 5 cells or more in the array of data. This information is obtained in the footnote (a) of Pallant (2007:289). Footnote (b) indicates preference that 0 cells $(0.0 \%)$ of the data array have a lower than expected count of 5 or less. The conclusion, therefore, is the higher the value, the better in both of these cases, whilst the lower the value, the higher the violation of the Chi-Square test (Pallant 2007).

The steps followed in the study (Pallant 2007) were:

Step 1: Chi-Square violation: If the assumptions of ChiSquare concerning 'minimum expected cell frequency' have been violated, this value should be 5 or higher. In the event that the Chi-Square has been violated the value should be 4578 and thus smaller than 5 (Pallant 2007).

Step 2: Significance: When the Chi-Square value is 4578 with an associated significance level of 0.47 presented in Asymp Sig the value is insignificant. To be significant, the Sig value needs to be 0.05 or smaller. If Sig > 0.05 (in this case 0.56 ) then the result is not significant (Pallant 2007).

Cramer's V explanation: Cramer's V takes into account the degrees of freedom. This is calculated by subtracting 1 from the number of categories under review in the rows, and additionally, on top of that, subtracting 1 from the number of categories under review in the columns, and select from these whatever variable is the smaller. This is explained as follows with the Chi-Square test for independence with Yates Continuity Correction:

$\chi_{(1, \mathrm{n}=94)=.221, \mathrm{p}=.221, \mathrm{phi} .2}^{2}$

[Eqn 1]

Where Phi is between 0 and 1 , the higher value indicates that the association between the variables is stronger (Pallant 2007).

From an ethical point, of view permission and clearance from both University of Johannesburg (UJ) and the retail chain in Gauteng was obtained. Furthermore, informed consent from the individual respondents when completing the questionnaire was obtained and anonymity was ensured. The researcher kept the data confidential and no information will be made available without consent from the participants.

\section{Results and discussion}

On the specific day the survey was conducted with a sample of 100 consumers at the retail store, $65.7 \%$ of the respondents that answered the questions were males, whilst only $34.3 \%$ were females. From a race perspective, 53.9\% were white people, $33.3 \%$ were black people, $5.9 \%$ were mixed race and $6.9 \%$ were Asian.

Tables 1 and 2 illustrate which payment method was preferred by different race and income groups respectively.

TABLE 1: The preference of either cash or card according to race.

\begin{tabular}{|c|c|c|c|}
\hline Preference & Related question & Black people (\%) & White people (\%) \\
\hline \multirow[t]{4}{*}{ Cash } & 2. Draw cash before spend & 13.7 & 21.2 \\
\hline & 4. Prefer wallet full of cash than cards & 90.3 & 82.2 \\
\hline & 6. Hate waiting for card transaction & 79.2 & 83.3 \\
\hline & 7. Scared of fraudulent transactions & 30.3 & 28.8 \\
\hline \multirow[t]{6}{*}{ Card } & 3. Card payments more durable than cash & 8 & 6.7 \\
\hline & 9. Quicker to pay with cash at POS & 50 & 64.6 \\
\hline & 12. Paying with cash is exactly the same as when paying with a card & 67.6 & 74 \\
\hline & 13. Pay with card even if transaction is below $R 40$ & 75 & 63.5 \\
\hline & 14. Often request cash with card transaction at POS & 40 & 30.6 \\
\hline & 15. Card is King & 87.9 & 90.2 \\
\hline
\end{tabular}

TABLE 2: The preference of either cash or card according to income.

\begin{tabular}{|c|c|c|c|c|c|c|}
\hline Preference & Related question & $\begin{array}{c}\text { R60k - R100k } \\
(\%)\end{array}$ & $\begin{array}{c}\text { R101k - R250k } \\
(\%)\end{array}$ & $\begin{array}{c}\text { R251k - R450k } \\
(\%)\end{array}$ & $\begin{array}{c}\text { R451k - R650k } \\
(\%)\end{array}$ & R651k (\%) \\
\hline \multirow[t]{3}{*}{ Cash } & 2. Draw cash before spend & 25.9 & 6.7 & 11.8 & 24 & 30 \\
\hline & 4. Prefer wallet full of cash than cards & 15.4 & 10.3 & 13.3 & 18.2 & 20 \\
\hline & 7. Scared of fraudulent transactions & 38.5 & 23.32 & 27.8 & 36.4 & 10 \\
\hline \multirow[t]{5}{*}{ Card } & 3. Card payments more durable than cash & 10.7 & 3.1 & 10.5 & 18.2 & 80 \\
\hline & 9. Quicker to pay with cash at POS & 69.9 & 48.3 & 76.5 & 50 & 41.7 \\
\hline & 13. Pay with card even if transaction is below $R 40$ & 64.5 & 65.4 & 31.6 & 50 & 60 \\
\hline & 14. Often request cash with card transaction at POS & 17.8 & 25 & 27.5 & 31.5 & 36.7 \\
\hline & 15. Card is King & 94.4 & 90 & 90.9 & 85.2 & 80 \\
\hline
\end{tabular}


In total, $76 \%$ of all consumers knew exactly which payment instrument they were going to utilise even before they entered a retail store to purchase goods, whether with cash, card or travellers cheques. This suggests that consumers have conducted an analysis of their current financial state of affairs before making the purchase of goods at the pay point. This might also be an indication that consumers were price-sensitive, knew exactly which goods they were going to purchase from the retail store at any given time and have ensured that they can service the account at that specific time.

It can, however, be that some of the consumers were habitual cash or card buyers. Consumers indicated that they had certain habits when it came to selecting their payment instrument. This is, according to Leinonen (2009:128), because of technological advances in the payment instrument arena. It is noted that the payment instrument has evolved over time and is currently best depicted by NFC with POS and its tap-and-go functionality. Almost $80 \%$ of the respondents reported that they selected their payment instrument out of habit, which is an indication that consumers evolved with the evolution of the payment instruments. As old payment instruments are replaced with newer instruments by banks the consumers are drawn into the payments area utilising their new device.

The Holmes study (2011:11) found that African-American consumers would rather make use of cash when paying for goods at a pay point in their country. Black consumers in this research indicated that they would rather pay with a card at POS than take money from ATM. Black respondents (90\%) also indicated that they would prefer money in their wallets than cards. This was also the case with white respondents, preferring a wallet full of cash, $82.2 \%$. There was a 50/50 split on which payment instrument is quicker to pay with at a pay point, with an overwhelming $75 \%$ agreement in paying with a card when the transaction cost is R40 or less. On answering whether cash or card is king, $81.7 \%$ advised that 'Card is King'.

The white respondents indicated that they would rather pay at the pay point with a card payment instrument than with cash they have withdrawn from the ATM. Seventynine percent of the white respondents suggested that they would not go to an ATM to withdraw money to pay for their goods. This is a direct contradiction of research conducted in developing economies, where the consumers would first search for an ATM and withdraw money to pay for their goods. In Pretoria, Gauten, the reasons for this might be because of costs associated with the ATM transaction, as you are allowed, for example, three free transactions and eight POS transactions per month from ABSA for a basic 'flexi' account (ABSA 2013). When asked directly why consumers did not want to make use of an ATM it was said that thieves watch you dog an ATM transaction and then steal the funds that were obtained from the ATM. The implication to the banking community is vast, as fewer ATMs are required in these areas, which leads to cost savings due to the roll-out of the physical ATM, maintenance, information technology requirements as well as the cash stock processes. $28.8 \%$ of the white respondents in comparison to $30.3 \%$ of the black respondents did not trust the POS devices and might have been a victim of fraud.

Respondents stated that the speed of the transaction did not matter, although they did not enjoy waiting for the card transaction to be processed. From this we notice that consumers in the retail store did not think that the transaction should be concluded fast, as long as it was concluded and did not take too long. This will be different per consumer, day and time the transaction takes place. Consumers want payment instruments that work and will work on the devices of the merchant. As long as the banking sector provides them with an instrument that can be utilised everywhere, the consumer would like to spend money.

When the preference of either cash or card payment is compared according to income, the interesting fact is that the income group between R101 000 and R450 000 was the least in favour of drawing cash at the ATM before spending money. The lower income group (R60 000 to R100 000) and higher income group (R451 000 to R651 000) would draw money from the ATM before shopping. This varied between $24 \%$ and $30 \%$. The overall feeling of all the respondents was the preference of a wallet full of cards rather than cash. However, everyone hates waiting for card transactions. In the income group between R451 000 and R650 000, 100\% of the respondents responded by indicating they hate waiting for a card transaction. This can be directly related to the fact that these respondents knew they had money available on their cards and linked to the question 'paying with the card is exactly the same as paying with cash'.

The high-income group (R651 000) was not as scared of fraudulent transactions at POS $-10 \%$ - as the income group earning R451 000 to R650 $000-36.4 \%$ - or the R60 000 to R100 000 income group - 38.5\%. It seems that fraudulent transactions are more of a scare to the lower income groups. All the income groups up to R650 000 found card payment not more durable than cash, with all measuring below $18.2 \%$. However, the + R651 000 income group found card payments $80 \%$ more durable than cash and found cash not quicker to pay at POS, contrary to all other income groups, who said just the opposite.

Not all the income groups were in favour of requesting cash with a card transaction at POS. The R60 000 - R100 000 group was the least interested, with only $17.8 \%$, and the R101 $000-$ R450 000 income group measuring between 25\% and 27.5\%. The group earning between R451 000 and R651 000 and more varied between $31.5 \%$ and $36.7 \%$. Finally, all income groups thought that cards were replacing cash and were therefore as important to have in your wallet as cash. On average $90 \%$ of respondents over all income groups agreed with this.

The merchant must also provide the consumer with a wide array of payment instrument options which is accepted by the merchant to drive payment acceptance at pay point up. 
Not only is the merchant responsible for accepting payment instruments, but the merchant is also required to provide the consumer with value-added services from technology platforms such as for instance cash back, electricity and mobile air time. From the results it was clear that consumers were not perturbed by these additional services at pay point in this particular retail store in Pretoria, Gauteng.

The majority of the consumers indicated that they did not request cash with a card transaction at POS. The implication for the merchant is that the cash in the pay point will have to be handled by an operations person internal to the store who has to count and bank the physical cash into a deposit box. Other costs that are associated with the cash is the handling fee from the security groups to collect the money, insurance cost against theft and fire, and of course the banking fees for depositing cash into the business transactional account. If the retail store can lower their cash deposits in the retail store, they will be able to cut the cost associated with cash handling.

There are multiple cash idioms to which the ordinary person gets exposed in a lifetime, and the one that resonates with most of us is probably the idiom 'strapped for cash', which relates to not having enough money. The academic term utilised by well-known strategist Porter (Stephenson \& Porter 2010:34-41), to indicate that a business has much cash in the bank is 'the cash cow'. 'Cash is King' is a wellrenowned idiom rather 'keep your money liquid in the form of cash', but when asking consumers whether 'Card is King' an overwhelming $85 \%$ of the respondents answered in the positive. It can be said that cash is slowly but surely losing face value and that the consumer is ready to evolve with a bit of a push into a cashless society. Is it purely because the consumers do not see any difference between card and cash, as both are mediums of exchange? However, consumers are often forced to carry cash for payment at certain services.

\section{Recommendations on further research}

It is necessary to look at what influences the selection of a payment instrument, and it is clear from the research that the sample under review does not necessarily align to the literature review and professionals' thoughts in developed and developing countries. Further research should be conducted on the effect of payment behaviour and attributes of the consumers when choosing a specific payment instrument. Verifone already indicated that $67 \%$ of the adult population in South Africa is unbanked (Verifone 2013).

An interesting study may be conducted into the 13 million unbanked adults in South Africa that made R8 billion cash deposits in 2012 (Mittner 2013) in terms of the cash used instead of cards. Walter Volker, chairman of the Payments Association of South Africa (PASA), stated that credit cards were utilised in one out of every two transactions. Combining rewards-related payment instruments with transactions performed at pay point will provide additional information on the payment habits of individuals; transactional information that will assist with a better understanding of rewards and the payment processes.

Many research opportunities exist in the utilisation of payment instruments. The South African market is at the front of usage of cards as payment and enjoying the benefits also associated to that. The question may be asked: What influences the decision to use a specific payment instrument?

\section{Conclusion}

The study was conducted to understand the utilisation of payment instruments in a retail store in Gauteng.

Of all the consumers, $76 \%$ knew exactly which payment instrument they were going to utilise before they entered a retail store to purchase goods, whether with cash or card. This indicates that consumers have conducted an analysis on their current financial state of affairs before making a purchase of goods at the pay point. This further indicates that consumers are price-sensitive, know what goods they are going to purchase at the given time and that they can service that account on the specific time.

Although cash is still the preferred payment instrument, the latest technology evolved to a new slogan: 'Card is King'.

Information regarding preferences amongst race groups and income were tested using the Cramer's V and the Chi-Square tests. Information obtained from this study may be fruitful for the retail industry on individual's choices of payment instruments at the point of sales.

\section{Acknowledgements Competing interests}

The authors declare that they have no financial or personal relationship(s) that may have inappropriately influenced them in writing this article.

\section{Authors' contributions}

A.M.B. (University of Johannesburg) master's research dissertation formed the basis for this article. S.B. (University of Johannesburg) was the supervisor of the study. Both authors contributed academic input to the study and in the writing of the article.

\section{References}

ABSA, 2013, Pricing structure, ABSA, Johannesburg.

Arango, C. \& Taylor, V., 2009, Merchants' costs of accepting means of payment: Is cash the least costly?, Bank of Canada review, Ottawa.

Bizhani, M. \& Tarokh, M.J., 2010, 'Behavioral segmentation of banks' point-of-sales using RF*M* Approach', IEEE, pp. 81-86.

Bolt, W., Jonker, N. \& Van Renselaar, C., 2010, 'Incentives at the counter: An empirical analysis of surcharging card payments and payment behaviour in the Netherlands', Journal of Banking \& Finance 34(8), 1738-1744. http://dx.doi.org/10.1016/j. jbankfin.2009.09.008

Borzekowski, R. \& Kiser, E.K., 2008, 'The choice at the checkout: Quantifying demand across payment instruments', International Journal of Industrial Organization 26(4), 889-902. 
Bounie, D., Francois, A. \& Houy, N., 2007, 'The demand for currency versus debitable accounts: A reconsideration, mimeo', [Online], viewed 11 October 2013, from http://ssrn.com/abstract $=987375$

Carow, K.A. \& Staten, M.E., 1999, 'Debit, credit, or cash: Survey evidence on gasoline purchases', Journal of Economics and Business 51, 409-421. http://dx.doi. org/10.1016/S0148-6195(99)00016-8

Cohn, L., 2010, Battle royal: Credit vs. debit, Kiplinger's personal finance, Washington, DC.

Contini, D., 2012, 'Consumer payment options', Communities \& Banking 16-17.

DataMonitor, 2011, What consumers want series, DataMonitor, London.

Evans, D.S., Webster, K., Colgan, G. \& Murray, S., 2013, Paying with cash: A multicountry analysis of the past and future of the use of cash for payments by consumers, Loomis AB, Stockholm.

Gogoski, R., 2012, 'Payment systems in economy - Present and future tendencies', Procedia - Social and Behavioral Sciences 44, 436-445. http://dx.doi. org/10.1016/j.sbspro.2012.05.048

Holmes, G., 2011, 'Card and mobile payment opportunities: A framework to conside potential winners and losers and a snapshot of the future payments landscape in Africa', Journal of Payments Strategy \& Systems 5(2), 134-142.

Howell, D.C., 2014, 'Chi-Square test - Analysis of contingency tables', [Online], viewed 1 July 2014, from http://www.indiana.edu/ educy520/sec5982/week_12/chi_ sq_summary011020.pdf

Humphrey, D.B., 2004, 'Replacement of cash by cards in U.S. consumer payments', Journal of Economics and Business 56, 211-225. http://dx.doi.org/10.1016/j. jeconbus.2003.09.001

Kahn, C.M. \& Roberds, W., 2009, 'Why pay? An introduction to payments economics', Journal of Financial Intermediation 18(1), 1-23. http://dx.doi.org/10.1016/j. jfi.2008.09.001

Kyobe, M., 2011, 'Investigating the key factors influencing ICT adoption in South Africa', Journal of Systems and Information Technology 13(3), 255-267. http:// dx.doi.org/10.1108/13287261111164844

Leinonen, H., 2009, Evolving payment habits, Bank of Finland, Helsinki, p. 4.

Mann, R.J., 2011, Adopting, using and discarding paper and electronic payment instruments: Variation by age and race, Federal Reserve Bank Boston, Boston.

Michael, R.S., 2014, 'Crosstabulation \& Chi-Square', [Online], viewed 1 July 2014, from http://www.indiana.edu/ educy520/sec5982/week_12/chi_sq_summary011020. pdf
Mittner, M., 2013, 'Unbanked market 'needs attention', [Online], viewed 11 October 2013, from http://www.bdlive.co.za/business/financial/2013/07/17/unbankedmarket-needs-attention

Pallant, J., 2007, SPSS survival manual, McGraw Hill Education, Berkshire.

Paygate, 2008, 'More ways to get paid online with payGate', - FNB Cell Pay Point. [Online], viewed 7 September 2011, from http://www.paygate.co.za/news. php?aid=16

Polasik, M., Górka, J., Wilczewski, G., Kunkowski, J. \& Przenajkowska, K., 2010, 'Time efficiency of point-of-sale payment methods: Preliminary results', Journal of Internet Banking and Commerce 15(3).

Ramlall, I., 2010, 'Do credit and debit cards induce an evaporation of cash in Mauritius?', International Research Journal of Finance and Economics 36, 16-24.

Schuh, S. \& Stavins, J., 2010, 'Why are (some) consumers (finally) writing fewer checks? The role of payment characteristics', Journal of Banking \& Finance 34(8), 1745-1758. http://dx.doi.org/10.1016/j.jbankfin.2009.09.018

Shoprite, 2002, 'Shoprite Checkers to accept debit cards', [Online], viewed 6 September 2011, from http://www.shopriteholdings.co.za/pages/1019812640/ news/articles/2002/SHOPRITE-CHECKERS-TO-ACCEPT-DEBIT-CARDS.asp

Stephenson, T. \& Porter, J., 2010, 'Really using an excel-based budget you've created', Strategic Finance $92,34-41$.

Ten Raa, T. \& Shestalova, V., 2004, 'Empirical evidence on payment media costs and switch points', Journal of Banking \& Finance 28, 203-213. http://dx.doi. org/10.1016/S0378-4266(02)00404-1

Todorova, Z., 2009, Centre for Full Employment and Price Stability (CFEPS), [Online] viewed 6 September 2011, from http://www.cfeps.org/pubs/wp-pdf/WP46Tcherneva.pdf

Verifone, 2013, 'VeriFone South Africa: Secure payment solutions \& point-of-sale (POS) systems', [Online], viewed 11 October 2013, from http://www.verifone. co.za/media/3323580/africa-mobile-infogaphic.pdf

Vickers, J., 2005, 'Public policy and the invisible price: Competition law, regulation and the interchange fee', Competition Law Journal 4(1), 5 .

Weinstein, S.B., 1984, 'Emerging telecommunications needs of the card industry', Institute of Electrical and Electronics Engineers Communications Magazine 22(7), 26-31. http://dx.doi.org/10.1109/MCOM.1984.1091995

Zdravkovic, A., 1988, 'Wireless point of sale terminal for credit and debit payment systems', Institute of Electrical and Electronics Engineers Communications Magazine 2, 890-893. http://dx.doi.org/10.1109/CCECE.1998.685641 